\title{
Matrine inhibits the expression of adhesion molecules in activated vascular smooth muscle cells
}

\author{
JUN LIU ${ }^{1}$, LIHUA ZHANG ${ }^{1}$, YINGANG REN ${ }^{1}$, YANLI GAO $^{1}$, LI KANG $^{1}$ and SHAOPING LU ${ }^{2}$ \\ Departments of ${ }^{1}$ Geriatrics and ${ }^{2}$ Cardiology, Tangdu Hospital, The Fourth Military Medical University, \\ Xi'an, Shanxi 710038, P.R. China
}

Received January 12, 2015; Accepted December 7, 2015

DOI: $10.3892 / \mathrm{mmr} .2016 .4767$

\begin{abstract}
Atherosclerosis is a chronic inflammatory disease associated with increased expression of adhesion molecules in vascular smooth muscle cells (VSMCs). Matrine is a main active ingredient of Sophora flavescens roots, which are used to treat inflammatory diseases. However, the effects of matrine on the expression of adhesion molecules in VSMCs have largely remained elusive. Therefore, the present study investigated the effects of matrine on the expression of adhesion molecules in tumor necrosis factor (TNF)- $\alpha$-stimulated human aortic smooth muscle cells (HASMCs). The results showed that matrine inhibited the expression of vascular cell adhesion molecule-1 (VCAM-1) and intercellular adhesion molecule-1 (ICAM-1) in TNF- $\alpha$-stimulated HASMCs. Matrine markedly inhibited the TNF- $\alpha$-induced expression of nuclear factor $(\mathrm{NF})-\kappa \mathrm{B}$ p65 and prevented the TNF- $\alpha$-caused degradation of inhibitor of NF- $\kappa \mathrm{B}$; it also inhibited TNF- $\alpha$-induced activation of mitogen-activated protein kinases (MAPKs). Furthermore, matrine inhibited the production of intracellular reactive oxygen species (ROS) in TNF- $\alpha$-stimulated HASMCs. In conclusion, the results of the present study demonstrated that matrine inhibited the expression of VCAM-1 and ICAM-1 in TNF- $\alpha$-stimulated HASMCs via the suppression of ROS production as well as $\mathrm{NF}-\kappa \mathrm{B}$ and MAPK pathway activation. Therefore, matrine may have a potential therapeutic use for preventing the advancement of atherosclerotic lesions.
\end{abstract}

\section{Introduction}

Atherosclerosis is now recognized as a chronic inflammatory disease of the vascular wall (1). Cell-cell and cell-matrix adhesion have important roles in the formation of atherosclerotic

Correspondence to: Dr Shaoping Lu, Department of Cardiology, Tangdu Hospital, The Fourth Military Medical University, 1 Xinsi Road, Baqiao, Xi'an, Shanxi 710038, P.R. China

E-mail: shaopinglutd@163.com

Key words: matrine, adhesion molecules, human aortic smooth muscle cells lesions (2). As the disease progresses, vascular smooth muscle cells (VSMCs) undergo phenotypic transformation and become activated to secrete pro-inflammatory cytokines and monocyte chemoattractant protein 1 , and express cell adhesion molecules that promote leukocyte recruitment, migration and differentiation (3). Accumulating evidence implied that vascular cell adhesion molecule-1 (VCAM-1) is upregulated in VSMCs of atherosclerotic lesions (4-6). Furthermore, in cultured VSMCs, interleukin-1 (IL-1) and tumor necrosis factor (TNF- $\alpha$ ) induced VCAM-1 and intercellular adhesion molecule-1 (ICAM-1) expression as well as monocyte adhesion to VSMCs $(7,8)$. Therefore, preventing the expression of these adhesion molecules on VSMCs may be a promising therapeutic approach for atherosclerosis.

Compelling evidence has revealed that certain natural products, particularly those from medicinal plants, may represent an ideal source to develop safe and effective agents for the management of atherosclerosis. Stereocalpin A, an active component of the Antarctic lichen Ramalina terebarata, prevented the induction of the expression of adhesion molecules in a concentration-dependent manner after stimulation with an inflammatory cytokine (9). Sulforaphane, a compound naturally occurring in Brassica oleracea var. italica (broccoli) and numerous other cruciferous vegetables, was also shown to inhibit the expression of TNF- $\alpha$-induced adhesion molecules in VSMCs (10).

Matrine is a major active component of Sophora flavescens roots, which are used to treat inflammatory diseases, including enteritis and hepatitis $(11,12)$. Besides its anti-inflammatory activity, matrine has been shown to affect the cardiovascular system. A previous study reported that matrine inhibits VSMC proliferation via upregulation of the p53/p21 signaling pathway (13). However, the effects of matrine on the expression of adhesion molecules in VSMCs have remained elusive. The purpose of the present study was to investigate the effects of matrine on adhesion molecule accumulation in TNF- $\alpha$-stimulated human aortic smooth muscle cells (HASMCs) as well as the underlying mechanisms of action. The results demonstrated that matrine suppressed TNF- $\alpha$-induced adhesion molecule expression through the inhibition of mitogen-activated protein kinase (MAPK) and nuclear factor (NF)- $\kappa \mathrm{B}$ signaling pathways and intracellular reactive oxygen species (ROS) production in HASMCs. 


\section{Materials and methods}

Materials. Matrine (purity, $>99 \%$ ) was purchased from the National Institute for the Control of Pharmaceutical and Biological Products (Beijing, China). Dulbecco's modified Eagle's medium, fetal bovine serum (FBS) and Lipofectamine Plus were purchased from Invitrogen (Thermo Fisher Scientific, Inc., Waltham, MA, USA). The pGL3-NF-kB vector and the luciferase assay system were provided by Promega (Madison, WI, USA), and the pCMV- $\beta$-gal vector was obtained from Lonza (Walkersville, MD, USA). Antibodies against ICAM-1 (mouse monoclonal) and VCAM-1 (mouse monoclonal) were purchased from R\&D Systems, Inc. (Minneapolis, MN, USA)

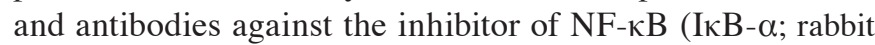
polyclonal), p65 (rabbit polyclonal), c-Jun N-terminal kinase (JNK; rabbit polyclonal), phospho-JNK (p-JNK; rabbit polyclonal), extra-cellular signal-regulated kinase (ERK; rabbit monoclonal), p-ERK (rabbit polyclonal), p38 (rabbit polyclonal), p-p38 (rabbit polyclonal), Akt, p-Akt, lamin A (rabbit polyclonal) and $\beta$-actin (rabbit polyclonal) were purchased from Abcam Inc. (Cambridge, MA, USA). PCR primers and PCR premix were purchased from Bioneer Corporation (Daejeon, South Korea). phosphate-buffered saline (PBS), tris-buffered saline (TBS) and Tween 20 were purchased from Sigma-Aldrich. (St. Louis, MO, USA).

Cell culture. HASMCs were purchased from Clonetics Corp. (San Diego, CA, USA) and cultured in DMEM medium (Gibco; Thermo Fisher Scientific, Inc.) supplemented with $100 \mathrm{IU} / \mathrm{ml}$ penicillin, $100 \mathrm{mg} / \mathrm{ml}$ streptomycin, and 5\% FBS (Invitrogen; Thermo Fisher Scientific, Inc.) with $2 \mathrm{ng} / \mathrm{ml}$ basic fibroblast growth factor, $10 \mathrm{ng} / \mathrm{ml}$ recombinant human epidermal growth factor and $5 \mu \mathrm{g} / \mathrm{ml}$ insulin (all from Sigma-Aldrich).

Cell viability assay. The effects of matrine on the proliferation of HASMCs were determined using the 3-(4,5-dimethylthiazol-2-yl)-2,5-diphenyltetrazolium bromide (MTT) assay. HASMCs were seeded onto 96-well plates $\left(1 \times 10^{4}\right.$ cells/well) and subsequently treated with various concentrations of matrine $(0,10,50$ and $100 \mu \mathrm{g} / \mathrm{ml})$. Following $72 \mathrm{~h}$ of incubation, MTT $(0.5 \mathrm{mg} / \mathrm{ml}$; Sigma-Aldrich) was added to each well. After incubation for $4 \mathrm{~h}$, the supernatant was removed and $0.1 \%$ dimethylsulfoxide (Sigma-Aldrich) was added to dissolve the formazan crystals. The absorbance at $550 \mathrm{~nm}$ was measured using a microplate reader 3350 (Bio-Rad Laboratories, Hercules, CA, USA) and the percentage of viable cells compared with that in the control group was calculated.

Reverse-transcription quantitative polymerase chain reaction ( $R T-q P C R)$. RNA extraction was performed with TRIzol reagent (Invitrogen; Thermo Fisher Scientific, Inc.) according to the manufacturer's instructions. Subsequently, RNA was reverse-transcribed in a 20 -ml reaction system using an Advantage RT kit (Clontech Laboratories, Inc., Palo Alto, CA, USA) according to the supplier's recommended protocol. mRNA levels were quantified by RT-qPCR using SYBRGreen Master Mix (Applied Biosystems; Thermo Fisher Scientific, Inc.) using a $30 \mathrm{ng}$ template in a $20 \mu \mathrm{l}$ reaction mixture. For PCR amplification, the following primers were used: VCAM-1 forward, 5'-CAAAGGTGG

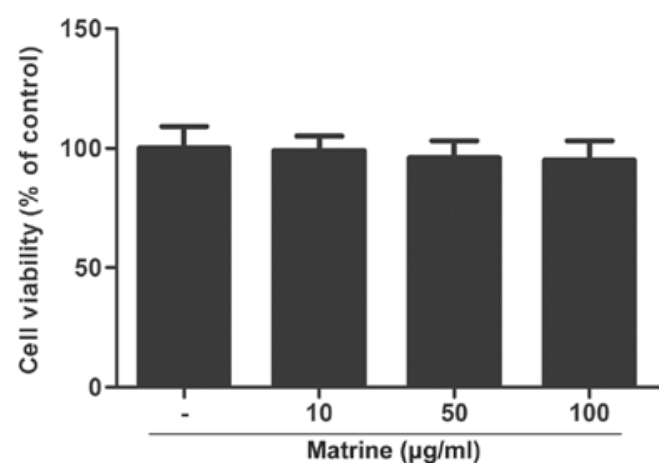

Figure 1. Effect of matrine on HAMSC viability. HAMSCs were treated with various concentrations $(0,10,50$ and $100 \mu \mathrm{g} / \mathrm{ml})$ of matrine for $24 \mathrm{~h}$. The cytotoxicity was then measured by an MTT assay. All experiments were repeated at least three times. Values are expressed as the mean \pm standard error of the mean. HAMSC, human aortic smooth muscle cell.

ATCAGATTCAAG-3' and reverse, 5;-GGTGAGCATTAT CACCCAGAA-3'; ICAM-1 forward, 5'-CAAAGGTGG ATCAGATTCAAG-3' and reverse, 5;-GGTGAGCATTAT CACCCAGAA-3'; GAPDH forward, 5'-CAAAGGTGG ATCAGATTCAAG-3' and reverse, 5;-GGTGAGCATTAT CACCCAGAA-3'. The PCR cycling program was $95^{\circ} \mathrm{C}$ for $3 \mathrm{~min}$, followed by 28 cycles of $95^{\circ} \mathrm{C}$ for $20 \mathrm{sec}, 60^{\circ} \mathrm{C}$ for $20 \mathrm{sec}$ and $72^{\circ} \mathrm{C}$ for $15 \mathrm{sec}$, and a final extension at $72^{\circ} \mathrm{C}$ for $5 \mathrm{~min}$. The levels of individual gene mRNA transcripts were initially normalized to the control $\beta$-actin. Subsequently, the differential expression of these genes was analyzed using the $2^{-\Delta \Delta \mathrm{Cq}}$ method (14).

Western blot analysis. HVSMCs were cultured and treated with matrine as described above and subsequently subjected to western blot analysis. After treatment, the cells were washed twice with PBS and suspended in $70 \mu \mathrm{l}$ of Buffer A [10 mM HEPES (pH 7.9), $1.5 \mathrm{mM} \mathrm{MgCl} 2,10 \mathrm{mM} \mathrm{KCl}$, $0.5 \mathrm{mM}$ DTT, $0.5 \mathrm{mM}$ PMSF and Protease Inhibitor Cocktail (Sigma-Aldrich)] and incubated on ice. After $15 \mathrm{~min}, 0.5 \%$ Nonidet P (NP)-40 was added to lyse the cells, which were vortexed for $1 \mathrm{sec}$. Then, cytosolic cell extracts were obtained after centrifuging at $1500 \mathrm{xg}$ for $10 \mathrm{~min}$ at $4^{\circ} \mathrm{C}$. The collected nuclei were resuspended in $50 \mu 1$ of Buffer $\mathrm{C}$ [ $20 \mathrm{mM}$ HEPES (pH 7.9), $1.5 \mathrm{mM} \mathrm{MgCl}_{2}, 420 \mathrm{mM} \mathrm{NaCl}, 0.2$ mM EDTA, 25\% v/v glycerol, 0.5 mM PMSF and Protease Inhibitor Cocktail] and incubated on ice for 20 min with intermittent agitation. Nuclear cell extracts were recovered after centrifugation for $10 \mathrm{~min}$ at $13,000 \mathrm{xg}$ at $4^{\circ} \mathrm{C}$. The protein concentration in the cell extracts was then determined using the Bradford protein dye reagent (Bio-Rad Laboratories, Inc.). Proteins ( $30 \mu \mathrm{g} / \mathrm{lane}$ ) were separated on $10 \%$ sodium dodecyl sulfate polyacrylamide gels (Bio-Rad Laboratories) and transferred onto polyvinylidene difluoride membranes (Millipore, Billerica, MA, USA). Membranes were blocked with $5 \%$ non-fat milk in TBST buffer $(50 \mathrm{mM}$ Tris, $\mathrm{pH} 7.5,250 \mathrm{mM} \mathrm{NaCl}, 0.1 \%$ Tween 20) and incubated with the appropriate primary antibodies overnight at $4^{\circ} \mathrm{C}$. Subsequent to washing the membranes three times with phosphate-buffered saline, 5 min per wash, containing $0.1 \%(\mathrm{v} / \mathrm{v})$ Tween 20 , membranes were incubated with horseradish peroxidase-conjugated secondary antibodies (MyBioSource, Inc., San Diego, CA, USA) for $1 \mathrm{~h}$, followed 

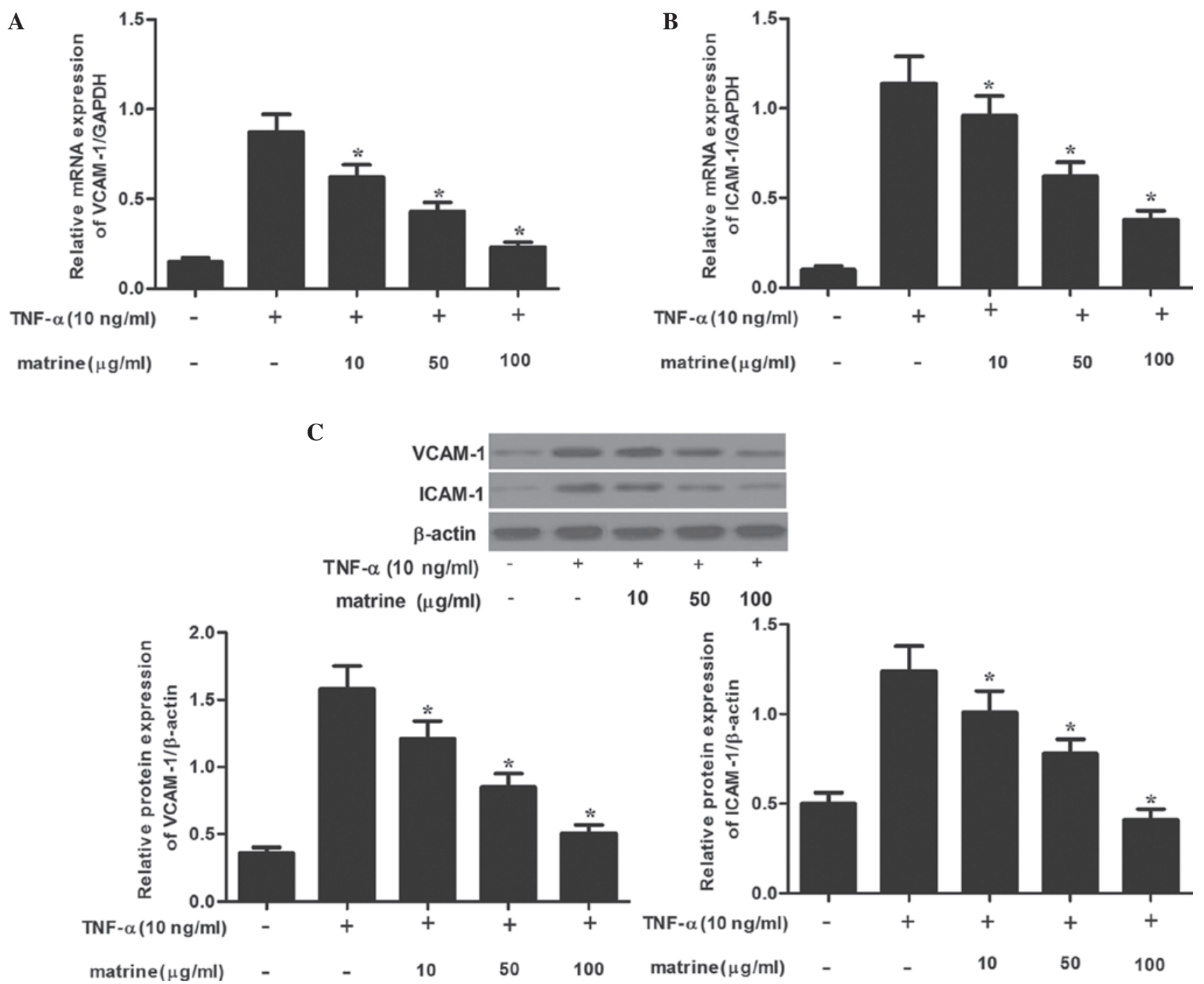

Figure 2. Effect of matrine on adhesion molecule expression in HAMSCs. HAMSCs were pre-incubated with various concentrations $(0,10,50$ and $100 \mu \mathrm{g} / \mathrm{ml}$ ) of matrine for $2 \mathrm{~h}$ and stimulated with TNF- $\alpha(10 \mathrm{ng} / \mathrm{ml})$ for $4 \mathrm{~h}$. mRNA expression of (A) VCAM-1 and (B) ICAM-1 was determined by reverse-transcription quantitative polymerase chain reaction analysis. (C) Protein expression of VCAM-1 and ICAM-1 was determined by western blot analysis. All experiments were repeated at least three times. Values are expressed as the mean \pm standard error of the mean. "P $<0.05$ vs. TNF- $\alpha$ group. HAMSC, human aortic smooth muscle cell. TNF, tumor necrosis factor; VCAM, vascular cell-adhesion molecule; ICAM, intercellular cell-adhesion molecule.

by visualization of the antibodies using enhanced chemiluminescence detection reagents. The blots were developed using an enhanced chemiluminescence kit (GE Healthcare Life Sciences, Chalfont, UK). Semi-quantitative determination of protein levels was performed using Image-Pro Plus software (NIH Image J 1.61; Media Cybernetics, Rockville, MD, USA).

Transfection and reporter assays. The cells $\left(1 \times 10^{5}\right.$ cells $\left./ \mathrm{ml}\right)$ were plated into each well of a 6 -well plate. The cells were transiently co-transfected with the plasmids, pGL3-NF-кB and pCMV- $\beta$-gal using Lipofectamine Plus according to the manufacturer's protocol. Briefly, a transfection mixture containing $0.5 \mu \mathrm{g}$ pGL3-NF-kB and $0.2 \mu \mathrm{g}$ pCMV- $\beta$-gal was mixed with the Lipofectamine Plus reagent and added to the cells. After $4 \mathrm{~h}$, the cells were pretreated with matrine, and then lysed with $200 \mu 1$ of lysis buffer ( $24 \mathrm{mM}$ Tris- $\mathrm{HCl}$ (pH 7.8), $2 \mathrm{mM}$ dithiotreitol, 2 mM EDTA, $10 \%$ glycerol, and $1 \%$ Triton X-100) and $10 \mu \mathrm{l}$ of cell lysates were used for luciferase activity assay. The luciferase and $\beta$-galactosidase activities were determined. The values shown represent an average of three independent transfections, which were normalized with $\beta$-galactosidase activity. Each transfection was performed in triplicate and experiments were repeated three times.

Assessment of ROS levels. ROS levels were determined according to the method of a previous study (15). 5,6-chloromethyl-2',7'-dichlorodihydrofluorescein diacetate $\left(\mathrm{CMH}_{2} \mathrm{DCFDA}\right.$; Molecular Probes, Eugene, OR, USA) was used to determined intracellular ROS levels using flow cytometry. Following pre-treatment of HASMCs $\left(3 \times 10^{6}\right.$ cells $\left./ \mathrm{ml}\right)$ with various concentrations of matrine for $2 \mathrm{~h}$, cells were incubated with TNF- $\alpha(10 \mathrm{ng} / \mathrm{ml})$ for $4 \mathrm{~h}$. The cells were then stained with $5 \mu \mathrm{M} \mathrm{CMH}_{2}$-DCFDA for $15 \mathrm{~min}$ at $37^{\circ} \mathrm{C}$. The cells were kept in the dark on ice and at least 10,000 cells for each sample were analyzed using a Becton Dickinson FACSCalibur (BD Biosciences, San Jose, CA, USA). Changes in the levels of intracellular ROS are expressed as a percentage of TNF- $\alpha$-stimulated, matrine-untreated cells. 

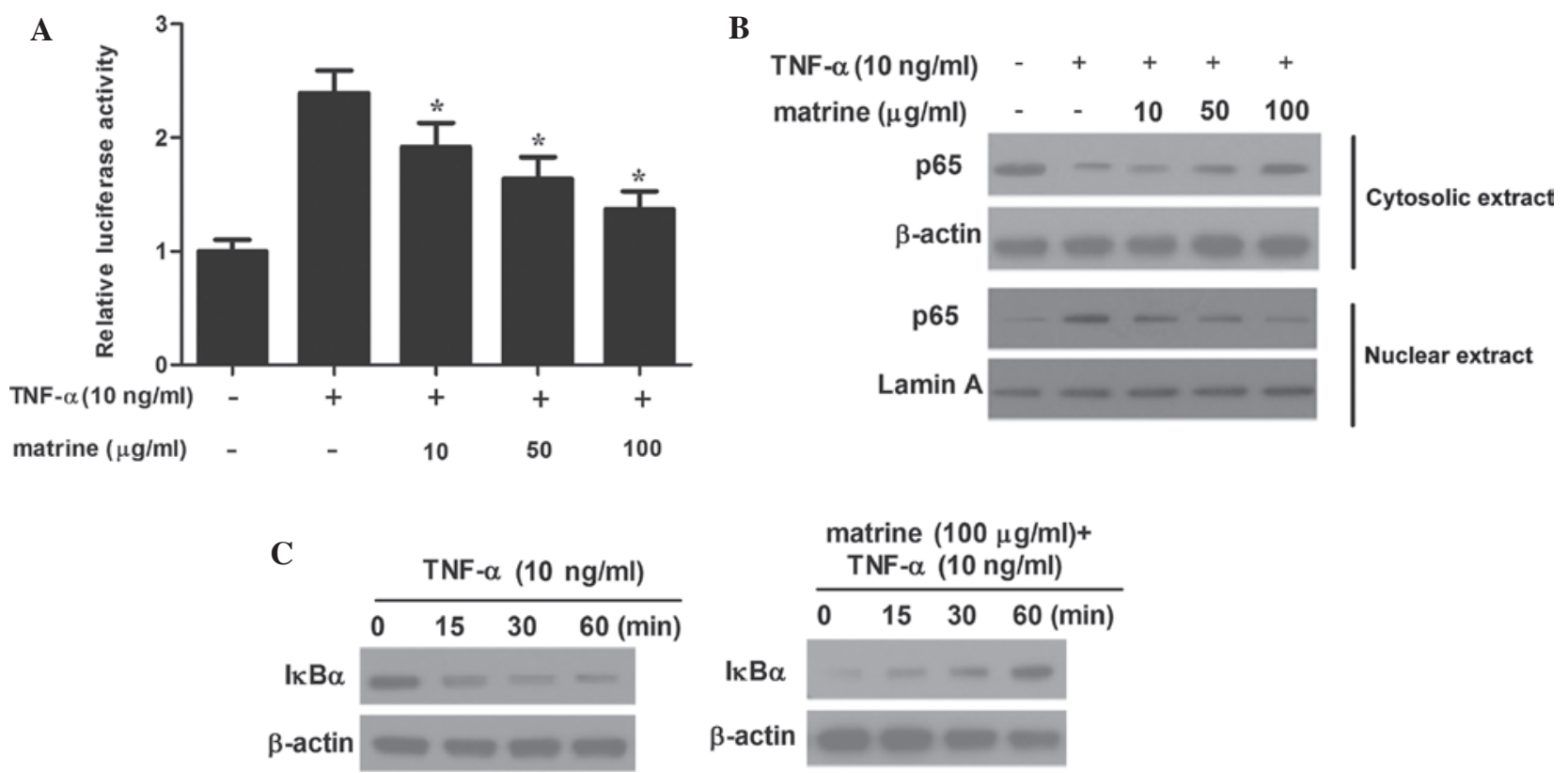

Figure 3. Effects of matrine on NF- $\kappa$ B activation and I $\kappa$ B $\alpha$ degradation in TNF- $\alpha$-stimulated HASMCs. (A) HAMSCs were transfected with a pGL3-NF- $\kappa$ B-Luc reporter plasmid and pCMV- $\beta$-gal, pre-treated with various concentrations of matrine $(0,10,50$ and $100 \mu \mathrm{g} / \mathrm{ml}) \mathrm{for} 2 \mathrm{~h}$ and stimulated with TNF- $\alpha$ for $4 \mathrm{~h}$. Values are expressed as the mean \pm standard error of the mean. ${ }^{*} \mathrm{P}<0.05$ vs. TNF- $\alpha$ group. (B) HAMSCs were pre-incubated with or without various concentrations of matrine for $2 \mathrm{~h}$ and then treated with TNF- $\alpha$ for $4 \mathrm{~h}$. Cytoplasmic and nuclear levels of NF- $\kappa \mathrm{B}$ p 65 were detected by western blot analysis to determine

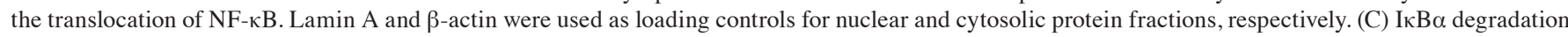
was analyzed by western blot analysis. All experiments were repeated at least three times. HAMSC, human aortic smooth muscle cell; NF- $\kappa \mathrm{B}$, nuclear factor kappa $\mathrm{B}$; I $\mathrm{B} \alpha$, inhibitor of $\mathrm{NF}-\kappa \mathrm{B}$; TNF, tumor necrosis factor.

Statistical analysis. Values are expressed as the mean \pm standard error of the mean. Data from different groups were compared using a Student's $t$-test or one-way analysis of variance followed by Dunnett's test. Statistical analysis was performed using SPSS (version 12.5S; SPSS, Inc., Chicago, IL, USA). $\mathrm{P}<0.05$ was considered to indicate a statistically significant difference.

\section{Results}

Matrine does not affect HAMSC viability. To examine the effect of matrine on cell viability, HASMCs were treated with various concentrations of matrine for $8 \mathrm{~h}$ and subjected to an MTT assay. As shown in Fig. 1, no significant cytotoxicity of matrine was observed. These observations indicated that matrine had no effect on the viability of HASMCs.

Matrine inhibits TNF- $\alpha$-mediated induction of adhesion molecules in HAMSCs. To examine whether matrine affects TNF- $\alpha$-mediated induction of adhesion molecules, HASMCs were pre-treated with various concentrations of matrine for $2 \mathrm{~h}$, followed by stimulation with TNF- $\alpha(10 \mathrm{ng} / \mathrm{ml})$ and subjected to RT-qPCR analysis. As shown in Fig. 2A and B, treatment with TNF- $\alpha$ induced the mRNA expression of VCAM-1 and ICAM-1 on HASMCs. However, matrine significantly inhibited TNF- $\alpha$-induced mRNA expression of VCAM-1 and ICAM-1 in a concentration-dependent manner. Consistent with these results, western blot analysis showed that matrine obviously suppressed TNF- $\alpha$-induced protein expression of VCAM-1 and ICAM-1 in a concentration-dependent manner (Fig. 2C). These results suggested that matrine effectively blocks TNF- $\alpha$-induced expression of VCAM-1 and ICAM-1.
Matrine inhibits TNF- $\alpha$-induced $N F-\kappa B$ activation in $H A M S C s$. Activation of NF- $\kappa \mathrm{B}$ is linked with the development of vascular damage; furthermore, transcription factors are known to mediate the expression of adhesion molecules (16). Therefore the present study examined the effects of matrine on $\mathrm{NF}-\kappa \mathrm{B}-$ mediated transcriptional activation. HASMCs were treated with various concentrations of matrine for $2 \mathrm{~h}$ and subsequently stimulated with TNF- $\alpha$ for $4 \mathrm{~h}$. Transcriptional activation assays were then employed to determine whether matrine affects NF- $\kappa \mathrm{B}$-dependent transcription. Stimulation with TNF- $\alpha$ obviously increased luciferase activity, while matrine significantly prevented this effect (Fig. 3A). Furthermore, the expression of $\mathrm{NF}-\kappa \mathrm{B}$ p 65 protein was detected by western blot analysis to clarify the inhibitory action of matrine. As shown in Fig. 3B, pre-treatment of HASMCs with matrine significantly decreased the nuclear levels of NF- $\kappa$ B p65, while simultaneously increasing its cytosolic levels. Furthermore, the effects of matrine on I $\mathrm{B}$ protein in TNF- $\alpha$-stimulated HASMCs were determined. TNF- $\alpha$ caused a significant degradation of $\mathrm{I} \kappa \mathrm{B} \alpha$ at $30 \mathrm{~min}$, which was inhibited by matrine (Fig. 3C). These results suggested that matrine impedes TNF- $\alpha$-induced NF- $\kappa \mathrm{B}$ activation.

Matrine inhibits TNF- $\alpha$-induced MAPK activation in HAMSCs. MAPK signaling is involved in the regulation of adhesion-molecule expression (16). Therefore, the present study investigated the effects of matrine on TNF- $\alpha$-induced phosphorylation of MAPKs in HAMSCs. As shown in Fig. 4, TNF- $\alpha$ significantly increased the activation of p38/MAPK, ERK1/2 and JNK in matrine-untreated cells. However, matrine concentration-dependently inhibited $\mathrm{TNF}-\alpha$-induced phosphorylation of MAPKs in HAMSCs. 

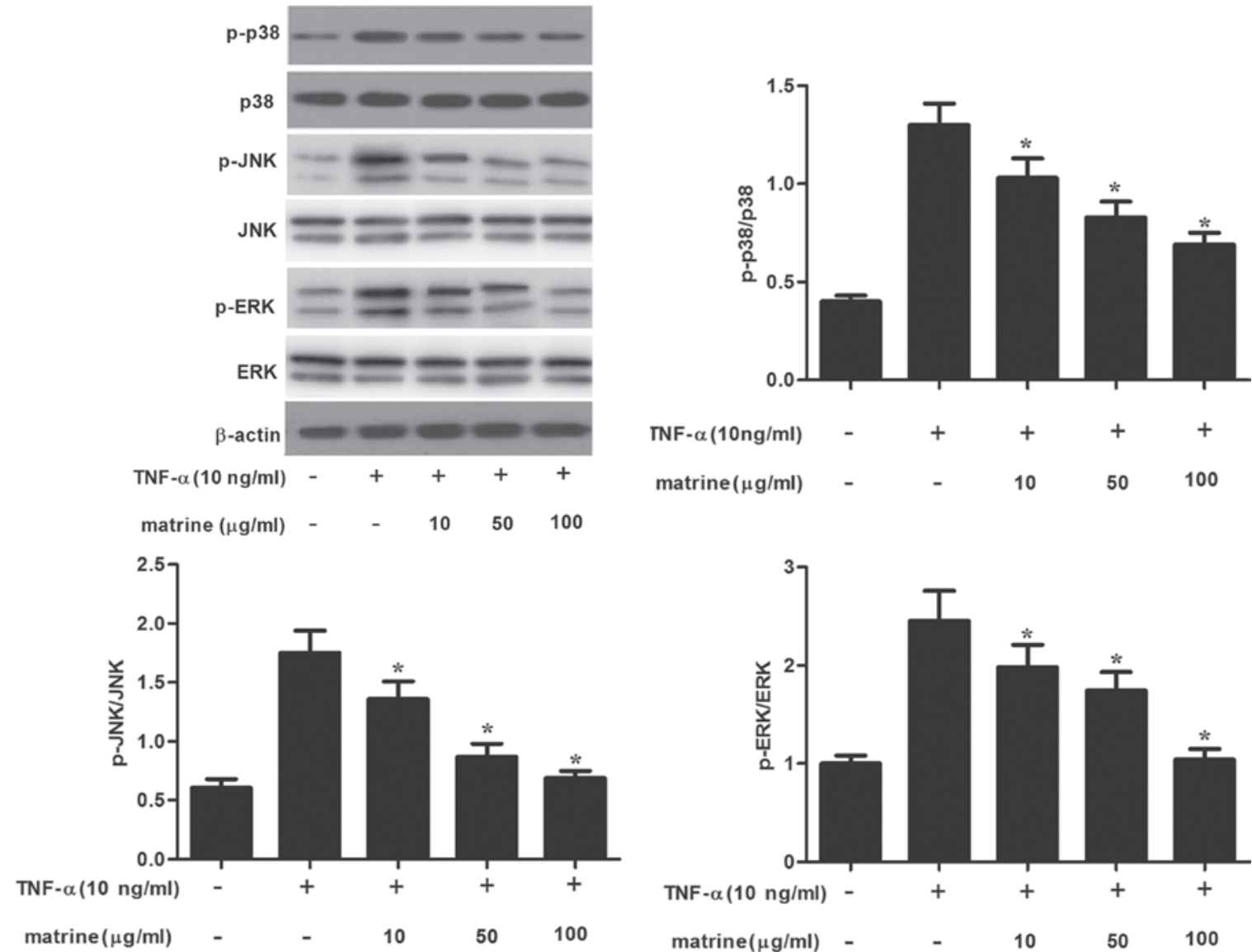

Figure 4. Effects of matrine on TNF- $\alpha$-induced phosphorylation of MAPKs in HAMSCs. HAMSCs were pre-treated with various concentrations of matrine $(0,10,50$ and $100 \mu \mathrm{g} / \mathrm{ml})$ for $2 \mathrm{~h}$ and then incubated with TNF- $\alpha(10 \mathrm{ng} / \mathrm{ml})$ for $30 \mathrm{~min}$. The relative intensities were expressed as the ratio of phospho-MAPK to total MAPK. Data were normalized to $\beta$-actin and are expressed as fold-changes of $\beta$-actin. All experiments were repeated at least three times. Values are expressed as the mean \pm standard error of the mean. $\mathrm{P}<0.05$ vs. TNF- $\alpha$ group. HAMSC, human aortic smooth muscle cell; MAPK, mitogen-activated protein kinase; p-ERK, phosphorylated extracellular signal-regulated kinase; TNF, tumor necrosis factor; JNK, c-Jun N-terminal kinase.

Matrine reduces ROS production in TNF- $\alpha$-stimulated HAMSCs. As it has been reported that TNF- $\alpha$-induced ROS production activates $\mathrm{NF}-\kappa \mathrm{B}$ in vascular cells, the present study investigated the effect of matrine on the production of TNF- $\alpha$-induced ROS production in HAMSCs (17). HAMSCs were pre-treated with matrine for $2 \mathrm{~h}$ and then stimulated with TNF- $\alpha$. As shown in Fig. 5, matrine significantly reduced the production of TNF- $\alpha$-induced ROS in a concentration-dependent manner. The production of ROS was reduced to $\sim 50 \%$ by the highest concentration of matrine $(100 \mu \mathrm{g} / \mathrm{ml})$.

\section{Discussion}

Cytokines such as IL-1 and TNF- $\alpha$ have been shown to induce the expression of cellular adhesion molecules VCAM-1 and ICAM-1 in atherosclerosis (18). VSMCs express VCAM-1 and ICAM-1, which are prominent in the fibrous caps of advanced atherosclerotic plaques (19). Therefore, pharmacological agents that inhibit the expression of these adhesion molecules have are potential drugs for inhibiting atherosclerosis. The present study showed that matrine inhibits the expression of VCAM-1 and ICAM- 1 in TNF- $\alpha$-stimulated HASMCs via the suppression of ROS production as well as $\mathrm{NF}-\kappa \mathrm{B}$ and MAPK pathway activation.

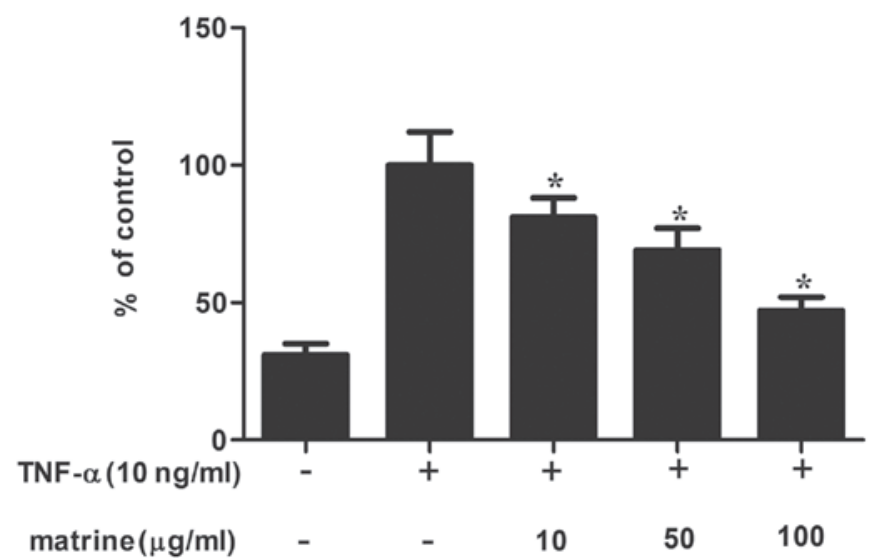

Figure 5. Effects of matrine on the production of ROS in TNF- $\alpha$-stimulated HAMSCs. HAMSCs were treated with various concentrations of matrine ( 0 , $10,50$ and $100 \mu \mathrm{g} / \mathrm{ml})$ for $2 \mathrm{~h}$ followed by stimulation with TNF- $\alpha(10 \mathrm{ng} / \mathrm{ml})$ for $4 \mathrm{~h}$ and determination of ROS levels. All experiments were repeated at least three times. Values are expressed as the mean \pm standard error of the mean. ${ }^{*} \mathrm{P}<0.05$ vs. TNF- $\alpha$ group. HAMSC, human aortic smooth muscle cell; ROS, reactive oxygen species; TNF, tumor necrosis factor.

A previous study showed that the expression of adhesion molecules, including VCAM-1 and ICAM-1, is increased in coronary atheroscleorotic tissue (20). In addition, inflammatory 
cytokines, including IL-1 $\beta$ and TNF- $\alpha$, increase the expression of VCAM-1 and ICAM-1 (21,22). The present study demonstrated that TNF- $\alpha$ significantly upregulated VCAM-1 and ICAM-1 expression in HAMSCs. These results were consistent with those of earlier published studies. However, matrine prevented the TNF- $\alpha$-induced expression of VCAM- 1 and ICAM-1. The present study showed that matrine has inhibitory effects on adhesion molecule expression in HASMCs stimulated with TNF- $\alpha$.

In all vascular cells implicated in the development of atherosclerosis, inflammatory mediators stimulate NF- $\mathrm{KB}$ activation (23-25). In quiescent cells, due to its association with $\mathrm{I} \kappa \mathrm{B}, \mathrm{NF}-\kappa \mathrm{B}$ is localized to the cytoplasm and unable to translocate to the nucleus (26). However, IкB is phosphorylated, ubiquitinated and subsequently degraded via the proteasome pathway in lipopolysaccharide- and cytokine-activated cells, which facilitates the nuclear translocation of $\mathrm{NF}-\mathrm{\kappa B}$, where it initiates the transcription of numerous genes, including pro-inflammatory cytokines, cell adhesion molecules and chemokines $(27,28)$. The results of the present study demonstrated that matrine decreased TNF- $\alpha$-induced NF- $\mathrm{KB}$ activation through inhibition of IкB kinase activation and subsequent I $\mathrm{K} B \alpha$ degradation. Collectively, these results revealed that the inhibitory effects of matrine on the expression of adhesion molecules is, at least partially, mediated through the suppression of NF- $\mathrm{KB}$ activation.

In addition to NF- $\kappa \mathrm{B}$, the MAPK signaling pathway also has a major role in diseases associated with vascular remodeling, as it regulates cell adhesion, proliferation, apoptosis and migration (29-31). TNF- $\alpha$-activated signaling pathways may also include MAPKs, which may mediate the resulting inflammatory responses (32). To better identify the effects of matrine on the MAPK signaling pathway, the present study assessed its impact on the levels of total and phosphorylated p38/MAPK, JNK and ERK1/2 in TNF- $\alpha$-treated HASMCs. The results revealed that the TNF- $\alpha$-induced phosphorylation of these MAPKs was significantly reduced by matrine in a concentration-dependent manner. Therefore, it was indicated that matrine downregulated adhesion molecule expression induced with TNF- $\alpha$ through inhibition of MAPK activation.

ROS serve as secondary messengers, which activate multiple signaling pathways, including NF- $\mathrm{kB}$ and MAPKs, leading to the induction of numerous downstream genes with essential roles in the physiology and pathophysiology of vascular cells $(27,33)$. In addition, the expression of adhesion molecules has been shown to be stimulated via the $\mathrm{NF}-\kappa \mathrm{B}$ signaling pathway, which was activated by induction of ROS (34). The results of the present study demonstrated that matrine significantly and concentration-dependently decreased the ROS production induced by TNF- $\alpha$. These findings indicated that in TNF- $\alpha$-treated HASMCs, matrine inhibits the activation of NF- $\mathrm{KB}$ and MAPKs via suppressing ROS production.

In conclusion, the results of the present study suggested that matrine reduced the expression of VCAM-1 and ICAM-1 in HASMCs stimulated with TNF- $\alpha$ via the suppression of ROS production and consequently of NF- $\kappa B$ and MAPK pathway activation. Therefore, matrine was indicated to be an effective anti-inflammatory agent with potential therapeutic use for preventing the advancement of atherosclerotic lesions.

\section{References}

1. Montecucco F and Mach F: Atherosclerosis is an inflammatory disease. Semin Immunopathol 31: 1-3, 2009.

2. Pollard TD and Borisy GG: Cellular motility driven by assembly and disassembly of actin filaments. Cell 112: 453-465, 2003.

3. Libby P and Li H: Vascular cell adhesion molecule-1 and smooth muscle cell activation during atherogenesis. J Clin Invest 92: 538-539, 1993.

4. Li H, Cybulsky MI, Gimbrone Ma-Jr and Libby P: An atherogenic diet rapidly induces VCAM-1, a cytokine-regulatable mononuclear leukocyte adhesion molecule, in rabbit aortic endothelium. Arterioscl Thromb 13: 197-204, 1993.

5. O'Brien KD, Allen MD, McDonald TO, Chait A, Harlan JM, Fishbein D, McCarty J, Ferguson M, Hudkins K, Benjamin CD, et al: Vascular cell adhesion molecule-1 is expressed in human coronary atherosclerotic plaques. Implications for the mode of progression of advanced coronary atherosclerosis. J Clin Invest 92: 945-951, 1993.

6. Teupser D, Thiery J, Haas U, Stein O, SteinY and Seidel D: Expression of vascular cell adhesion molecule-1 (VCAM-1) in the aortae of hypercholesterolemic rabbits with high (HAR) and low (LAR) atherosclerotic response. Atherosclerosis 128: 157-164, 1997.

7. Braun M, Pietsch P, Felix S and Baumann G: Modulation of intercellular adhesion molecule-1 and vascular cell adhesion molecule-1 on human coronary smooth muscle cells by cy tokines. J Mol Cell Cardiol 27: 2571-2579, 1995.

8. Thorne SA, Abbot SE, Stevens CR, Winyard PG, Mills PG and Blake DR: Modified low density lipoprotein and cytokines mediate monocyte adhesion to smooth muscle cells. Atherosclerosis 127: 167-176, 1996.

9. Byeon HE, Park BK, Yim JH, Lee HK, Moon EY, Rhee DK and Pyo S: Stereocalpin A inhibits the expression of adhesion molecules in activated vascular smooth muscle cells. Int Immunopharmacol 12: 315-325, 2012.

10. Kim JY, Park HJ, Um SH, Sohn EH, Kim BO, Moon EY, Rhee DK and Pyo S: Sulforaphane suppresses vascular adhesion molecule-1 expression in TNF- $\alpha$-stimulated mouse vascular smooth muscle cells: Involvement of the MAPK, NF- $\kappa \mathrm{B}$ and AP-1 signaling pathways. Vascul Pharmacol 56: 131-141, 2012.

11. Tan HR and Zhang BH: Experimental study of the anti-inflammatory effect of matrine. Zhong Xi Yi Jie He Za Zhi 5: 108-110, 1985 (In Chinese).

12. Long Y,Lin XT, Zeng KL and Zhang L: Efficacy of intramuscular matrine in the treatment of chronic hepatitis B. Hepatobiliary Pancreat Dis Int 3: 69-72, 2004.

13. Zhu P, Chen JM, Chen SZ, Zhang C, Zheng SY, Long G, Chen J, Zhou ZL, Fan RX, Fan XP, et al: Matrine inhibits vascular smooth muscle cell proliferation by modulating the expression of cell cycle regulatory genes. Acta Pharmacol Sin 31: 1329-1335, 2010.

14. Banning A, Schnurr K, Böl GF, Kupper D, Müller-Schmehl K, Viita H, Ylä-Herttuala S, Brigelius-Flohé R: Inhibition of basal and interleukin-1-induced VCAM-1 expression by phospholipid hydroperoxide glutathione peroxidase and 15-lipoxygenase in rabbit aortic smooth muscle cells. Free Radic Biol Med 36: 135-144, 2004.

15. Lee SR, Kwak JH, Kim HJ and Pyo S: Neuroprotective effects of kobophenol A against the withdrawal of tropic support, nitrosative stress, and mitochondrial damage in SH-SY5Y neuroblastoma cells. Bioorg Med Chem Lett 17: 1879-1882, 2007.

16. Kim JY, Park HJ, Um SH, Sohn EH, Kim BO, Moon EY, Rhee DK and Pyo S: Sulforaphane suppresses vascular adhesion molecule-1 expression in TNF- $\alpha$-stimulated mouse vascular smooth muscle cells: involvement of the MAPK, NF- $\kappa$ B and AP-1 signaling pathways. Vascul Pharmacol 56: 131-141, 2012.

17. Byeon HE, Um SH, Yim JH, Lee JH and Pyo S: Ohioensin F suppresses TNF- $\alpha$-induced adhesion molecule expression by inactivation of the MAPK, Akt and NF- $\mathrm{B}$ pathways in vascular smooth muscle cells. Life Sci 90: 396-406, 2012.

18. Libby P, Ridker PM and Maseri A: Inflammation and atherosclerosis. Circulation 105: 1135-1143, 2002.

19. Kasper HU, Schmidt A and Roessner A: Expression of the adhesion molecules ICAM, VCAM, and ELAM in the arteriosclerotic plaque. Gen Diagn Pathol 141: 289-294, 1996.

20. Yang PY, Rui YC, Lu L, Li TJ, Liu SQ, Yan HX and Wang HY: Time courses of vascular endothelial growth factor and intercellular adhesion molecule-1 expressions in aortas of atherosclerotic rats. Life Sci 77: 2529-2539, 2005. 
21. Zhang F, Yu W, Hargrove JL, Greenspan P, Dean RG, Taylor EW and Hartle DK: Inhibition of TNF-alpha induced ICAM-1, VCAM-1 and E-selectin expression by selenium. Atherosclerosis 161: 381-386, 2002.

22. Chen YH, Lin SJ, Chen JW, Ku HH and Chen YL: Magnolol attenuates VCAM-1 expression in vitro in TNF-alpha-treated human aortic endothelial cells and in vivo in the aorta of cholesterol-fed rabbits. Br J Pharmacol 135: 37-47, 2002.

23. De Martin R, Hoeth M, Hofer-Warbinek R and Schmid JA: The transcription factor NF-kappaB and the regulation of vascular cell function. Arterioscler Thromb Vasc Biol 20: E83-E88, 2000

24. Browatzki M, Schmidt J, Kübler W and Kranzhöfer R: Endothelin-1 induces interleukin-6 release via acctivation of the transcription factor NF-kappaB in human vascular smooth muscle cells. Basic Res Cardiol 95: 98-105, 2000.

25. Csiszar A, Smith K, Labinskyy N, Orosz Z, Rivera A and Ungvari Z: Resveratrol attenuates TNF-alpha-induced activation of coronary arterial endothelial cells: Role of NF-kappaB inhibition. Am J Physiol Heart Circ Physiol 291: H1694-H1699, 2006.

26. Baeuerle PA and Baltimore D: I kappaB: A specific inhibitor of the NF-kappaB transcription factor. Science 242: 540-546, 1988.

27. Baeuerle PA and Henkel T: Function and activation of NF-kappaB in the immune system. Annu Rev Immunol 12: 141-179, 1994.

28. Ledebur HC and Parks TP: Transcriptional Regulation of the intercellular adhesion molecule-1 gene by inflammatory cytokines in human endothelial cells essential roles of a variant kappaB site and p65 homodimers. J Biol Chem 270: 933-943, 1995.
29. Kingsley K, Huff JL, Rust WL, Carroll K, Martinez AM, Fitchmun M and Plopper GE: ERK1/2 mediates PDGF-BB stimulated vascular smooth muscle cell proliferation and migration on laminin-5. Biochem Biophys Res Commun 293: 1000-1006, 2002.

30. Rajesh M, Mukhopadhyay P, Hasko G, Huffman J, Mackie K and Pacher P: CB2 cannabinoid receptor agonists attenuate TNF-alpha-induced human vascular smooth muscle cell proliferation and migration. Br J Pharmacol 153: 347-357, 2008.

31. Li M, Liu Y, Dutt P, Fanburg BL and Toksoz D: Inhibition of serotonin-induced mitogenesis, migration, and ERK MAPK nuclear translocation in vascular smooth muscle cells by atorvastatin. Am J Physiol Lung Cell Mol Physiol 293: L463-L471, 2007.

32. Ju JW, Kim SJ, Jun CD and Chun JS: p38 Kinase and c-Jun $\mathrm{N}$-terminal kinase oppositely regulates tumor necrosis factor alpha-induced vascular cell adhesion molecule-1 expression and cell adhesion in chondrosarcoma cells. IUBMB Life 54: 293-299, 2002.

33. Griendling KK, Sorescu D, Lassègue B and Ushio-Fukai M: Modulation of protein kinase activity and gene expression by reactive oxygen species and their role in vascular physiology and pathophysiology. Arterioscl Thromb Vasc Biol Vas 20: 2175-2183, 2000

34. Qin P, Tang X, Elloso MM and Harnish DC: Bile acids induce adhesion molecule expression in endothelial cells through activation of reactive oxygen species, NF-kappaB and $\mathrm{p} 38$. Am J Physiol-Heart Circ Physiol 291: H741-H747, 2006. 